\title{
Peningkatan Daya Saing Usaha Mikro (UMi) Melalui Keuangan Inklusi
}

\author{
Yolanda Masnita*1, Khomsiyah ${ }^{2}$, Hermien Triyowati $^{3}$ \\ 1,2,3, Fakultas Ekonomi dan Bisnis, Universitas Trisakti \\ E-mail: yolandamasnita@trisakti.ac.id¹
}

\begin{abstract}
Microbusiness (UMi) is a business run by the people that are categorized as inferior or near-poor. The family-owned company, using local resources and simple technology. UMi is an unbanked people group, a group that is difficult to get access to banking even though this group has the potential to develop business. The purpose of this activity is to provide briefing and understanding on how to improve the role of UMi, become more resilient and reliable in conducting business, which in the end is expected to have an impact on improving the welfare of UMi itself. The main difficulties in developing UMi are lack of capital and lack of knowledge for business development. This activity was carried out in collaboration by LKMS through the Karya Syariah Mandiri Cooperative Work (KKUMS) and the Usakti Community Service Team. KKUMS assisted with capital, Abdimas FEB Team assisted in entrepreneurship. Collaboration between the two institutions increased wealth, and UMi knowledge brought about an impact on improving the welfare of the perpetrators of UMi in Sasakpanjang village, Bojong Gede District, Bogor Regency.
\end{abstract}

Keywords: Microbusiness - UMi, Unbanked people, Islamic Microfinance Institutions - LKMS, Entrepreneurship, Public servant

\begin{abstract}
Abstrak
Usaha mikro (UMi) adalah usaha yang dijalankan oleh rakyat yang dikategorikan miskin atau mendekati miskin. Usaha yang dimiliki oleh keluarga, menggunakan sumber daya lokal dan teknologi sederhana. UMi termasuk kelompok unbanked people, kelompok yang sulit mendapat akses perbankan padahal kelompok ini potensial dalam mengembangkan usaha. Tujuan kegiatan ini adalah memberikan pembekalan dan pemahaman cara meningkatkan peran UMi, menjadi lebih tangguh dan handal dalam melaksanakan usaha, yang pada akhirnya diharapkan akan berdampak pada peningkatan kesejahteraan UMi itu sendiri. Kesulitan utama pengembangan UMi yaitu kekurangan modal dan kekurangan pengetahuan untuk pengembangan usaha. Kegiatan ini dilakukan kerjasama oleh LKMS melalui Koperasi Karya Usaha Mandiri Syariah (KKUMS) dan Tim Abdi Masyarakat FEB Usakti. KKUMS membantu permodalan, Tim Abdimas FEB melakukan pendampingan kewirausahaan. Kolaborasi kedua lembaga tersebut, menghasilkan peningkatan permodalan dan pengetahun UMi membawa dampak peningkatan kesejahteraan kepada para pelaku UMi di desa Sasakpanjang, Kecamatan Bojong Gede, Kabupaten Bogor.
\end{abstract}

Kata Kunci: Usaha Mikro (UMi), Unbanked people, Lembaga Keuangan Mikro Syariah (LKMS), Wirausaha, Abdi Masyarakat (Abdimas)

\section{PENDAHULUAN}

Usaha Mikro (UMi) menurut Undang-Undang Nomor 20 Tahun 2008 Pasal 6 adalah usaha produktif milik orang perorangan dan atau badan usaha perorangan yang memiliki kriteria (i) Memiliki kekayaan bersih paling banyak Rp 50 juta tidak temasuk tanah dan bangunan tempat usaha; atau (ii) Memiliki hasil penjualan tahunan paling banyak Rp 300 juta. Menurut Departemen Tenaga Kerja (Depnaker) usaha mikro adalah usaha yang memiliki kurang dari 5 orang tenaga kerja. Sedangkan, menurut SK. Direktur BI No.31/24//Kep/DER tanggal 5 Mei 1998), usaha mikro (UMi) adalah usaha yang dijalankan oleh rakyat miskin atau mendekati miskin. Dimiliki oleh keluarga, menggunakan sumber daya lokal dan teknologi sederhana. Lapangan usaha, mudah untuk exit dan entry. Perkembangan usaha mikro, mempunyai peran yang cukup tinggi bagi perekenomian Indonesia. Perbedaan tingkat ekonomi yang ada mengakibatkan kebutuhan setiap golongan menjadi berbeda satu sama lainnya (Masnita et al., 2019; Bongomin et al., 2016). Untuk golongan ekonomi tinggi, akan memenuhi kebutuhan hidup dengan dana tinggi dan sebaliknya untuk golongan menengah kebawah akan memenuhi kebutuhan hidup sesuai budget yang dimiliki (Bongomin et al., 2018; Masnita et al., 2019). Karena itu kehadiran usaha mikro UMi, turut membantu kebutuhan berbagai golongan penghasilan tersebut (Martinus et al., 2020). 
Dari segi karakteristiknya, usaha mikro termasuk usaha yang dilakukan oleh masyarakat kalangan bawah, yang memulai usahanya dengan modal yang kecil, biasanya tidak lebih dari 10 juta rupiah. Modal yang digunakan adalah modal sendiri atau modal keluarga. Modal yang keĉil ini, memotivasi banyak usaha mikro baru masuk pasar, untuk memulai bisnisnya. Fenomena yang terjadi dewasa ini, usaha mikro terus menïngkatkan inovasi-inovasi baru lainnya, seperti berbagai jenis makanan/minuman baru, sehingga kehadiran outlet-outlet banyak ditemui.

Sampai saat ini terdapat 2 (dua) masalah utama dihadapi oleh UMi, yaitu (i) masalah permodalan, dan (ii) Masalah pemahaman konsep wirausaha. Permasalahan modal tersebut timbul karena UMi masih belum menjalankan bisnisnya dengan prinsip-prinsip manajemen modern, tidak/belum memiliki badan usaha resmi, ijin usaha, serta keterbatasan asset. Berdasarkan fakta ini, maka dalam rangka mengembangkan usahanya, UMi memerlukan tambahan modal, yang bisa diperoleh melalui lembaga formal Bank atau Non Bank, atau melalui penyedia dana informal seperti rentenir.

Disisi lain, faktanya sebagian besar UMi adalah merupakan unbanked people, yaitu kelompok masyarakat yang tidak bisa memperoleh pinjaman dari lembaga jasa keuangan formal (Masnita et al., 2019), seperti Bank, karena tidak bisa memenuhi persyaratan yang ditentukan. Menurut World Bank, 2008, baru 52\% penduduk Indonesia menggunakan jasa keuangan formal dan $79 \%$ penduduk miskin belum memiliki akses ke layanan keuangan formal, karena ketidak mampuan membuat dan menyediakan persyaratan pengajuan pembiayaan modal (ijin usaha, agunan/jaminan, laporan keuangan).

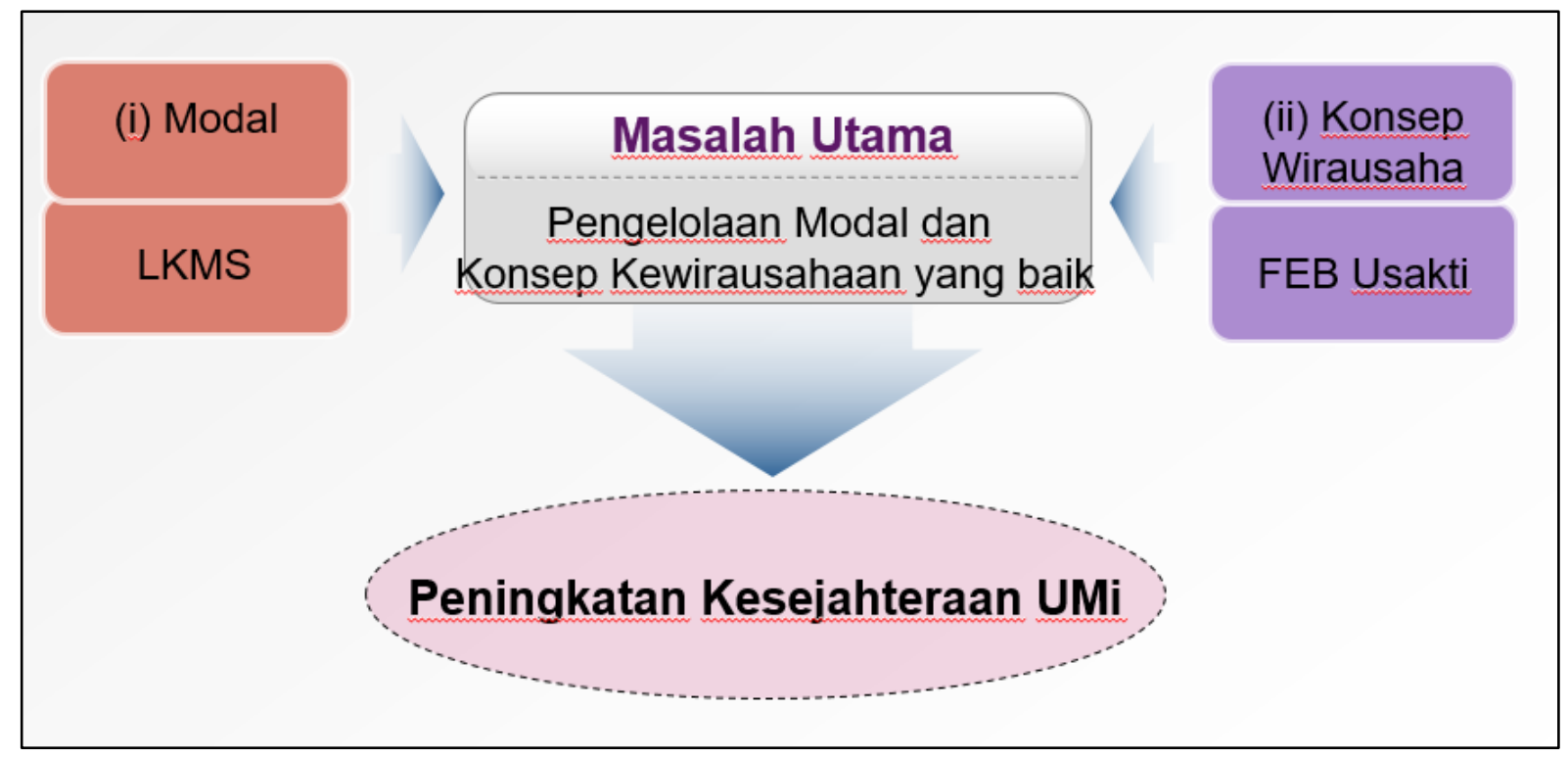

Gambar 1. Skema Permasalahan Utama UMi

Dengan memperhatikan kondisi yang dialami UMi, maka OJK (Otoritas Jasa Keuangan) menyelenggarakan program keuangan inklusif, yaitu penyediaan akses efektif terhadap pembiayaan, tabungan, transfer dan asuransi, melalui Lembaga Keuangan, untuk kelompok berpenghasilan rendah, tidak memiliki agunan, pelayanan nyaman, bertanggung jawab, biaya terjangkau, adil, transparan dan diatur oleh U.U. (Bank Indonesia, 2014).

Salah satu penyelenggara program ini adalah LKMS (lembaga keuangan mikro syariah), yang tidak berorientasi profit, menggunakan prinsip Syariah (Nasution, 2010; Triyowati \& Yolanda, 2016; Masnita et al., 2019). Sementara itu, program keuangan inklusif yang dibawah Perbankan antara lain dilaksanakan oleh BPRS (Bank Pembiayaan Rakyat Syariah). BPRS ini menyalurkan keuangan inklusif melalui koperasi - koperasi (chanelling), yang selanjutnya disebarkan kepada usaha-usaha mikro kecil yang membutuhkan pembiayaan/ modal, yang berlokasi diwilayah operasionalnya. Dengan memperhatikan berbagai uraian tersebut, maka dibentuk tim Abdimas (Abdi Masyarakat) FEB Usakti untuk memberikan pembekalan bagi Usaha 
Mikro - khususnya nasabah Koperasi (chanelling BPRS). Para nasabah ini merupakan pengusahapengusaha mikro, seperti penjual makanan (bakso, rempeyek, sate) dan minuman (es doger, cendol), pedagang sayur mayur, yang berada di desa Sasakpanjang Bojong Gede, Kecamatan Tajurhalang, Kabupaten Bogor. Team memberikan informasi dan pemahaman bagaimana cara meningkatkan peran UMK, menjadi lebih tangguh dan handal dalam melaksanakan usaha, yang pada akhirnya diharapkan akan berdampak pada peningkatan kesejahteraan UMi itu sendiri.

\section{METODE}

Sasaran kegiatan ini adalah unbanked people, orang - orang yang tidak memiliki akses untuk dapat pinjaman resmi ke bank. Disebabkan tidak memiliki agunan sebagai salah satu syarat dalam pengajuan pinjaman. LKMS melalui Koperasi Karya Usaha Mandiri Syariah (KKUMS), memberikan pinjaman kepada para UMi di desa Sasakpanjang, Kecamatan Bojong Gede, Kabupaten Bogor. Caranya dengan membuat kelompok usaha per RT. Setiap individu boleh mengajukan pinjaman ke KKUMS berkisar antara dibawah Rp 1 Juta sampai dengan Rp 15 Juta. Pengajuan pinjaman harus melalui RT, sehingga terdaftar dengan jelas tempat tinggal masing masing. Pinjaman dan pembayaran dilakukan dengan menggunakan buku pembayaran dari Koperasi dengan Skim Pembiayaan Mikro untuk Rumah Tangga Miskin, seperti terlihat pada gambar 2

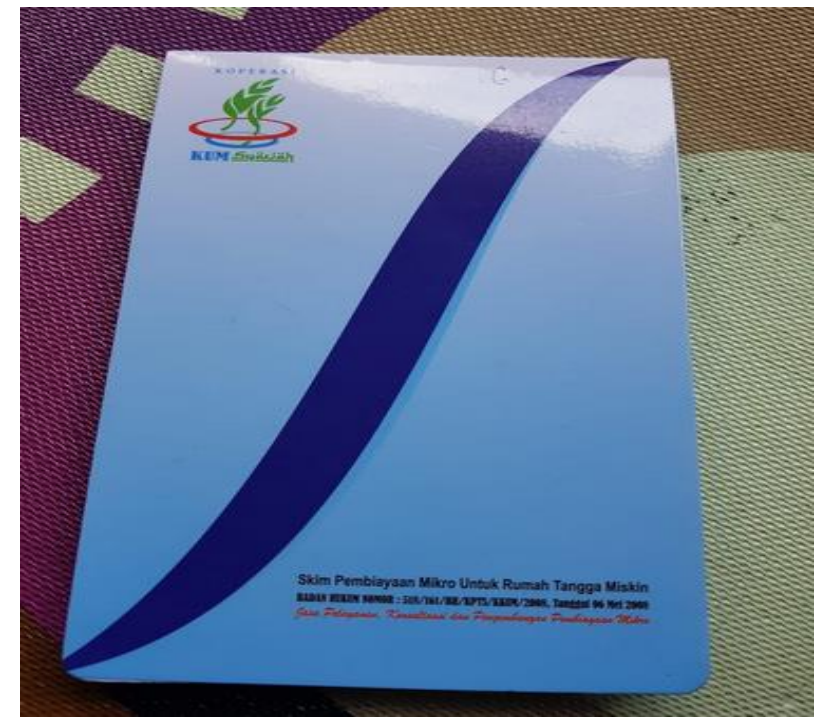

Gambar 2. Buku Simpan Pinjam Skim Pembiayaan Mikro untuk Rumah Tangga Miskin Koperasi Karya Usaha Mandiri Syariah (KKUMS)

Setiap minggu UMi akan: (i) melaporkan perkembangan usahanya, (ii) mencicil pinjamannya, (iii) mendapatkan konsultasi usaha. Kegiatan selalu dimulai dengan doa bersama, diikuti yel - yel penyemangat. Selanjutnya pihak koperasi dan RT akan membuka acara, mendengarkan laporan perkembangan usaha. Selanjutnya masing - masing UMi akan membayarkan cicilan pinjamannya ke pihak KKUMS, sementara yang sebagian lainnya akan berkonsultasi dengan team Abdimas FEB Usakti. Waktu yang dibutuhkan tergantung banyak atau sedikitnya anggota di RT. Jika banyak, maka akan membutuhkan waktu yang lama dan sebaliknya. Seperti di RT 09, anggota yang terdaftar sebanyak 18 orang. Ini membutuhkan waktu 2 jam. Setelah selesai di satu RT, maka dilanjutkan ke RT berikutnya. Kegiatan dilakukan di rumah masing - masing RT. 


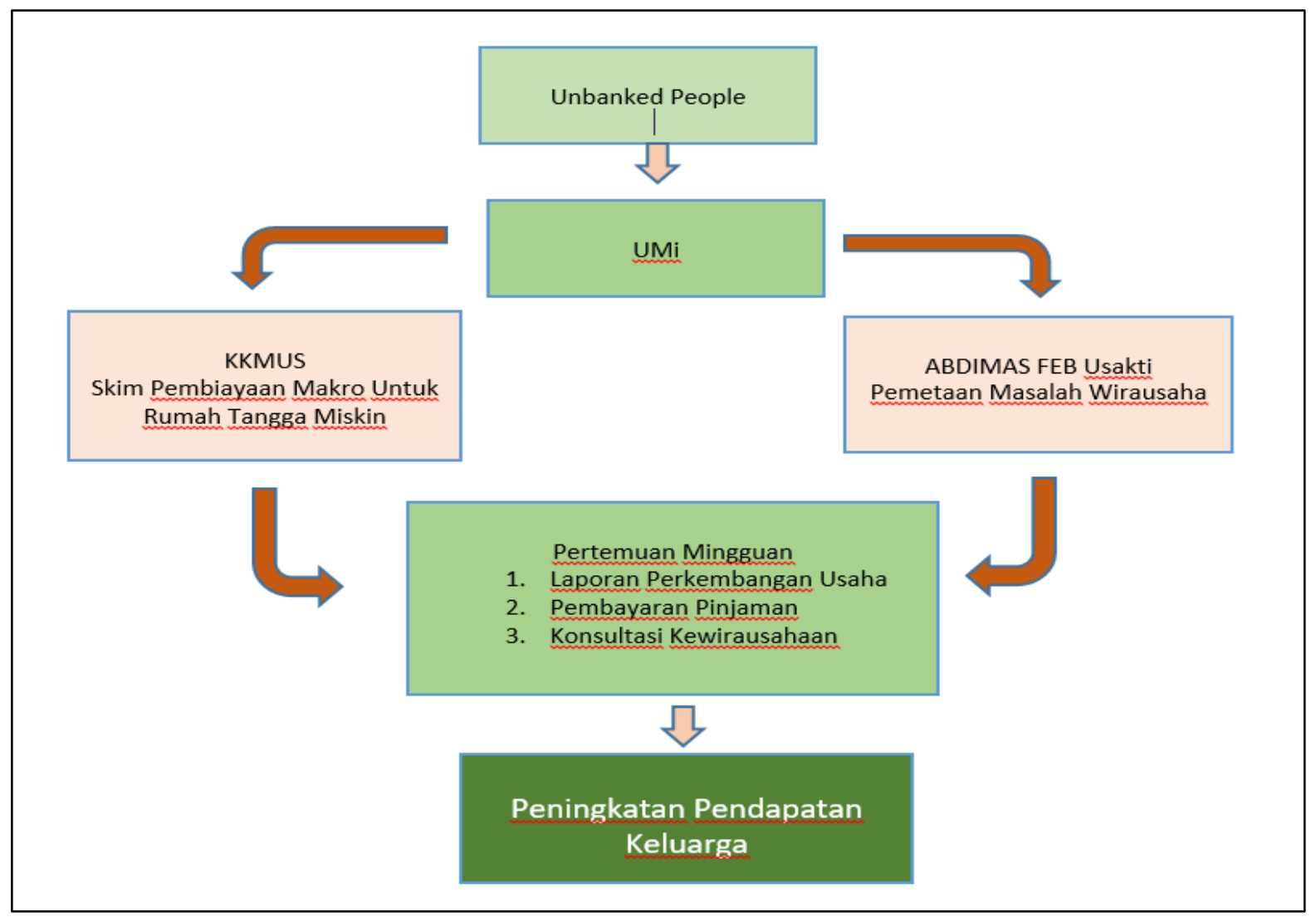

Gambar 3. Alur Pelaksanaan Peningkatan Daya Saing UMi

\section{HASIL DAN CAPAIAN}

Kegiatan Abdimas ini dilaksanakan dengan pemberian pembekalan kepada target peserta, disertai pelatihan dan penyuluhan, dan diakhiri dengan diskusi dan tanya jawab, terkait dengan permasalahan yang dihadapi peserta PKM. Metode pendekatan masalahnya adalah mencari jawaban atas permasalahan UMi, melalui pemberian materi dan pemahaman terkait kelembagaan UMi, yang meliputi: (i) Apa arti penting dari UMi dan bagaimana memulai UMi, apa manfaat membantu dan berkolaborasi dengan sesama UMi, dalam rangka peningkatan kesejahteraan masyarakat. (ii) Apa yang dimaksud dengan Ijin Usaha Mikro dan Kecil (IUMK), bagaimana cara pengurusan IUMK dan apa manfaat nya bagi pengembangan bisnis untuk UMi yang memiliki IUMK. (iii) Apa yang dimaksud dengan Bisnis Online, dan bagaimana cara melakukan bisnis online dalam rangka mempertahankan dan meningkatkan UMi agar tetap exis / ada dipasaran.

Adapun rancangan evaluasi pelaksanaan post program Abdimas adalah dengan memantau perkembangan UMi secara berkala, melalui pendampingan manajemen, dengan waktu dan tempat sesuai kesepakatan, dimana dalam jangka panjang, kegiatan ini, diharapkan akan menumbuh kembangkan dan meningkatkan kesejahteraan UMi.

\section{Subyek/ Sasaran Kegiatan}

UMi yang menjadi objek atau sasaran adalah nasabah dari produk pembiayaan usaha mikro yang dilakukan oleh Koperasi Karya Usaha Mandiri Syariah, yang merupakan chanelling BPRS (Bank Pembiayaan Rakyat Syariah) cabang Bogor. Terdapat banyak UMi yang merupakan nasabah Koperasi Usaha Mandiri Syariah, pada kegiatan kali ini secara acak dipilih $38 \mathrm{UMi}$, khususnya yang berlokasi di desa Sasakpanjang kecamatan Bojong Gede Bogor. Data responden $100 \%$ adalah wanita, dengan usia peserta beragam, terbanyak berusia 39 - 44 tahun sebesar 26,32\%. Dari sisi pendidikan tertinggi, terbanyak berpendidikan SMP sebesar 52,63\%. Dan 
81.58\% berstatus menikah. Sedangkan jumlah tanggungan keluarga, sebanyak 55,26\% kurang dari 3 orang; 34,.21\% menanggung keluarga antara 3-5 orang dan sebanyak 10,53\% mempunyai tanggungan keluarga lebih dari 5 orang.

Dari sisi jenis usaha mikro yang dimiliki, sebanyak 13.33\% peserta adalah perajïn payet untuk pakaian dan kerudung muslimah, sebanyak $36.67 \%$ penjual makanan \& minuman, sebanyak $36.67 \%$ penjual sayur mayur dan sebanyak $3.33 \%$ adalah penjual Alat Tulis dan Buku untuk anak sekolah. Penghasilan per bulan yang diperoleh pelaku UMi ini adalah, kurang dari Rp 2.000.000 sebanyak 36.67\%; antara Rp 2.000.000 - Rp 5.000.000 sebanyak 33.33\% dan lebih dari Rp 5.000.000 sebanyak 16.67\%.

Selain itu dari status kepemilikan, UMi berstatus usaha milik sendiri sebanyak 83.33\%. Sebagian besar bentuk badan usaha, adalah Usaha Mikro, yang belum mempunyai Ijin Usaha Mikro (IUMK), dengan lama usaha berdiri, kurang dari 3 tahun sebanyak 3,33\%, antara 5-10 tahun sebanyak $16.67 \%$, antara $10-15$ tahun sebanyak $23,3 \%$ dan lebih dari 15 tahun sebanyak $43.33 \%$. Adapun jumlah tenaga kerja yang sebagian besar adalah kerabat dekat atau keluarga, maka UMi dengan tenaga kerja kurang dari 5 orang sebanyak 6,67\% dan yang mempunyai tenaga kerja 510 orang sebanyak $80 \%$.

Terkait dengan jumlah pembiayaan yang diperoleh UMi dari Koperasi Usaha Mandiri Syariah, maka sebanyak 13,16\% menerima dana kurang dari Rp. 1.000.000; sebanyak 7,89\% memperoleh dana antara Rp. 1.000 .000 s.d Rp. 5.000.000; sebanyak 15,79\% memperoleh dana antara Rp. 5,000.000 s.d Rp. 10.000 .000 dan 63.16\% memperoleh dana antara Rp. 10.000 .000 s.d Rp. 15.000.000.
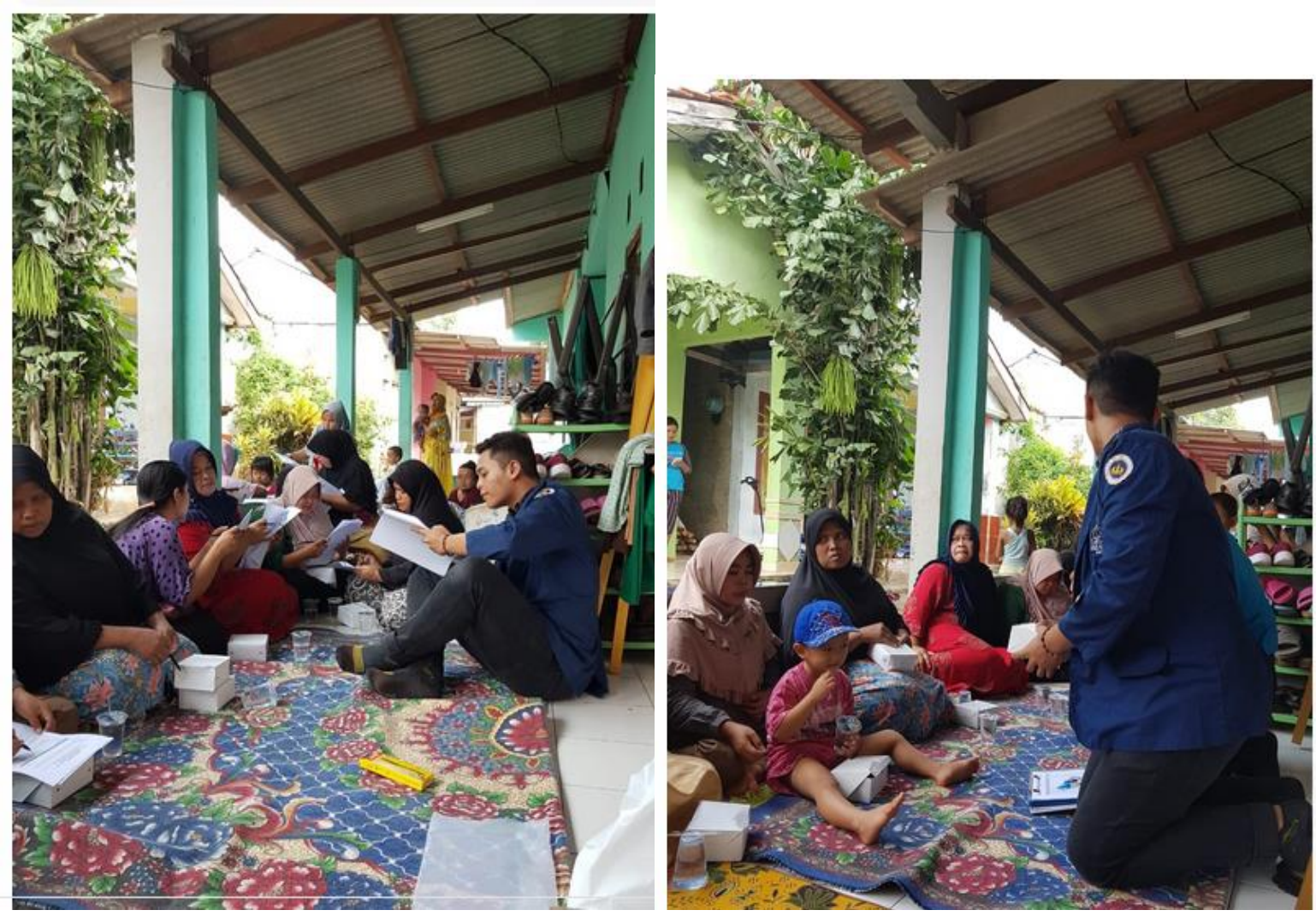

Gambar 4. Pendampingan Kewirausahaan Dibantu Para Mahasiswa

\section{Faktor Pendukung dan Penghambat}

Pelaksanaan kegiatan berjalan sesuai rencana. Pelaksanaan dilakukan dalam bentuk ceramah dan tanya jawab saja, materi - materi diberikan secara langsung dan ada catatn - catatan 
kecil dalam bentuk hardcopy modul. Dalam sesi tanya jawab, terungkap bahwa para peserta jarang sekali menerima pembekalan terkait pengembangan UMi mereka, seperti kewirausahaan, pembukuan sederhana, dan pemasaran produk. Ini terbukti dari pembukuan mereka yang masih gabung dengan pengeluaran rumah tangga, legalitas usaha mereka yang tidak atau belum memiliki ijin usaha, belum adanya kerjasama diantara para UMi, dan ketidak tahuan tentang bisnis online, walaupun sebagian besar peserta memiliki hand phone android.

Disisi lain para peserta juga hanya pernah menerima sedikit pengarahan terkait pengembangan kelembagaan mereka dari pihak koperasi, yang lebih banyak memberikan pengetahuan menyangkut kelancaran transaksi pembiayaan (pinjaman) antara mereka dengan pihak koperasi, dan itupun dalam waktu relative singkat tanpa adanya kesinambungan.

Disisi lain, pelaksanaan program pembiayaan khususnya bagi UMi, oleh koperasi, sudah banyak diminati oleh UMi. Program pembiayaan ini merupakan bagian dari kegiatan inklusi keuangan dari BPRS, dimana pelaksanaannya melalui koperasi syariah, yang dalam hal ini oleh Koperasi Karya Usaha Mandiri Syariah. Sebagai bagian dari kegiatan inklusi keuangan yang merupakan program nasional dari OJK (Otoritas Jasa Keuangan), maka seharusnya program ini juga disertai kegiatan literasi serta pembinaan ekonomi dan manajemen terhadap para pelaku UMi (Lungile \& Sylvanus, 2017). Namun dalam prakteknya, BPRS melalui koperasi, belum banyak melakukan pembinaan terhadap UMi secara menyeluruh, terkait pengembangan kelembagaan. Dalam hal ini, koperasi sebagai lembaga channeling BPRS, lebih menekankan tehadap pengembalian pembiayaan. Sehingga kerjasama antara LKMS dan institusi Perguruan Tinggi yang berkesinambungan sangat diperlukan.

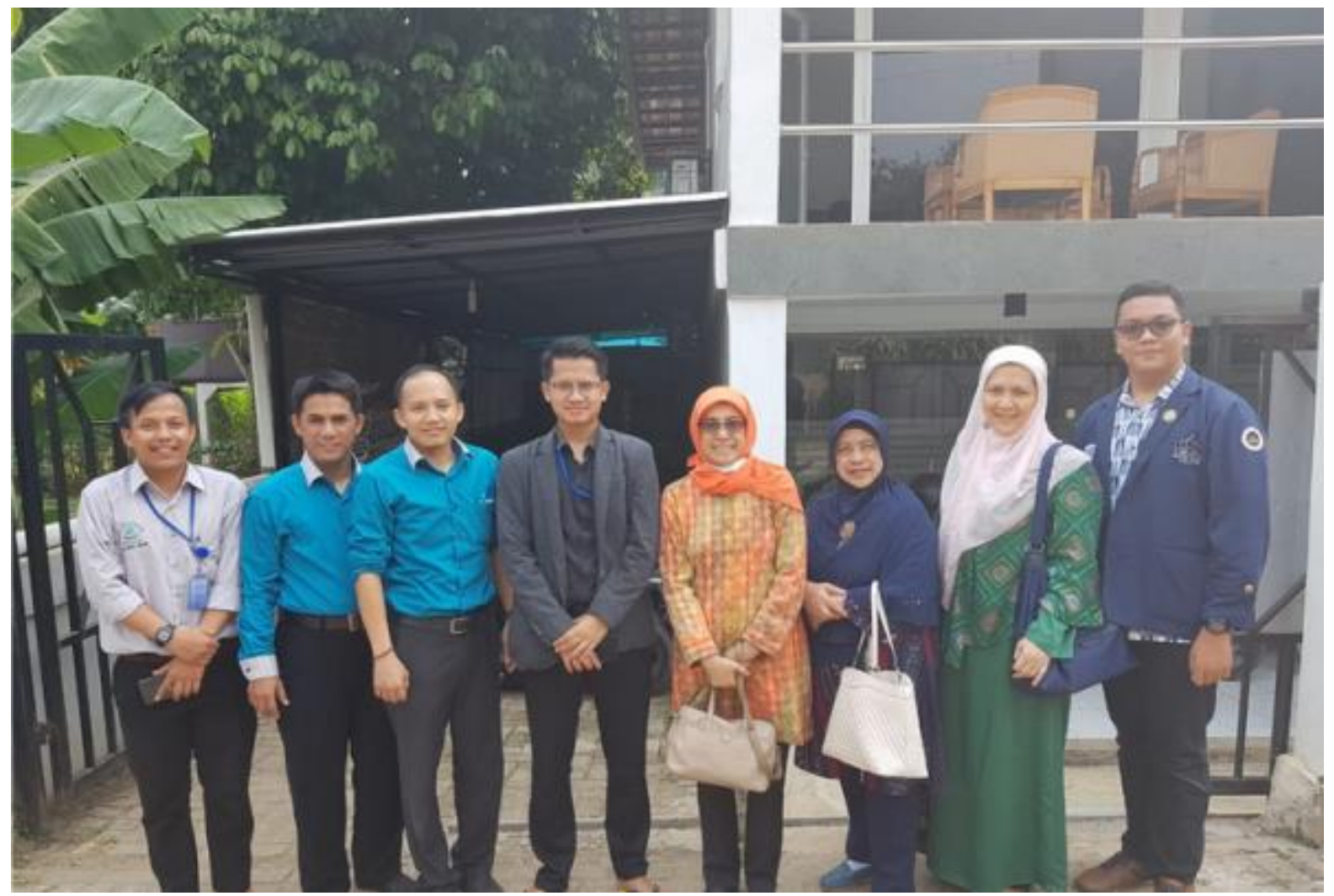

Gambar 5. Tim KKUMS dan Abdimas FEB Usakti

\section{KESIMPULAN DAN REKOMENDASI}


Melalui pemberdayaan ini, diharapkan bisa memberikan manfaat baik dalam jangka pendek maupun dalam jangka panjang. Pelaksanaan program Abdimas ini dirasakan sangat dibutuhkan dan sangat penting bagi pelaku UMi khususnya dan masyarakat pada umumnya, dan diharapkan akan berdampak terhadap peningkatan kesejahteraan UMi dan masyarakat.

Selain itu, pemberdayaan yang dilakukan membawa dampak peningkatan kualitas pengetahuan pelaku UMi - terkait, arti, makna, manfaat dan tujuan dari UMi dan bagaimana mengembangkan serta mempertahankan-nya. Memperbaiki kinerja UMi, yang pada akhirnya akan meningkatkan jumlah lembaga maupun jumlah tenaga kerja UMi, sehingga volume output meningkat, yang diharapkan berdampak kepada peningkatan pendapatan dan kesejahteraan UMi (Husam \& Saima, 2018).

Selanjutnya, berdasarkan kenyata-an ini maka disarankan untuk meningkatkan kerjasama lebih lanjut antara Abdimas FEB Usakti dengan beberapa Koperasi Syariah sebagai channeling BPRS, dalam hal pemberdayaan ekonomi dan manajemen untuk masyarakat pelaku Usaha Mikro. Sehingga dapat memberikan hasil yang maksimal untuk masyarakat.

\section{DAFTAR PUSTAKA}

Bank Indonesia. (2014). Booklet of inclusive finance. Department of Development of Financial Access and MSME's. Available at: < https://www.bi.go.id> [Accessed on 10 April 2020].

Bongomin, G. O. C., Ntayi, J. M., and Munene, J. (2018). Nexus between financial literacy and financial inclusion. International Journal of Bank Marketing, 36(7), pp. 1190-1212. https://doi.org/10.1108 /IJBM -08-2017-0175.

Bongomin, G. O. C., Ntayi, J. M., and Munene, J., (2016). Institutional frames for financial inclusion of poor households in Sub-Saharan Africa - Evidence from rural Uganda. International Journal of Social Economics, 43(11), pp. 1096-1114. https://doi.org/10.1108/IJSE-062014-0110.

Husam-Aldin Nizar Al-Malkawi, Saima Javaid. (2018). Corporate social responsibility and financial performance in Saudi Arabia: Evidence from Zakat contribution, Managerial Finance, Vol. 44 Issue: 6, pp.648-664, https://doi.org/10.1108/MF-12-2016-0366.

Lungile Ntsalaze, Sylvanus Ikhide.(2017). The threshold effects of household indebtedness on multidimensional poverty, International Journal of Social Economics, Vol. 44 Issue: 11, pp.1471-1488, https://doi.org/10.1108/IJSE-03-2016-0086

Masnita, Yolanda., Hermien Triyowati, and Khomsiyah. (2019). Application of Financial Inclusion In Indonesia: A Study On Vulnerable Group, Eurasian Journal of Economics and Finance, 7(3), 22-33. DOI: 10.15604/ejef.2019. 07.03.003.

Masnita, Yolanda., Hermien Triyowati, and Khomsiyah. (2020). Empowerment of Sharia Financial Institutions in Improving the Role of Financial Inclusions, Jurnal Wahana Abdimas Sejahtera. Volume 1, Nomor 1, halaman 26 - 37, November 2019. p-ISSN 1234-5678; e-ISSN 1122-3344.

Masnita, Yolanda., Hermien Triyowati, Khomsiyah, and Yuswar ZB. (2019). Bank Dan Lembaga Keuangan Lainnya: Tinjauan Manajemen Inklusi Keuangan, Lembaga Penerbit Universitas Trisakti, Jakarta.

Martinus Maslim, Stephanie Pamela Adithama, Andreas Hemawan Tri Nugroho. (2020). Pembangunan Sistem Informasi Penjualan Pada Usaha Mikro, Kecil, Dan Menengah (Studi Kasus : Pahala Fotokopi dan Digital Printing). DINAMISIA: Jurnal Pengabdian Kepada Masyarakat, Vol. 4, No. 1, Hal. 95-105. DOI: https://doi.org/ 10.31849/dinamisia.v4i1.3363

Nasution, Darmin. (2010). Welcoming Remarks, At The 2010 AFI Global Policy Forum, DenpasarBali.

Triyowati, Hermien., and Yolanda Masnita. (2016). The Role of Financial Inclusion Movement For Development of Micro And Small Enterprises (MSES), Entrepreneurship And Poverty Alleviation. International Journal of Technical Research and Application, Volume 4, Issue 1, PP 71-76. ISSN: 2320-8163. 